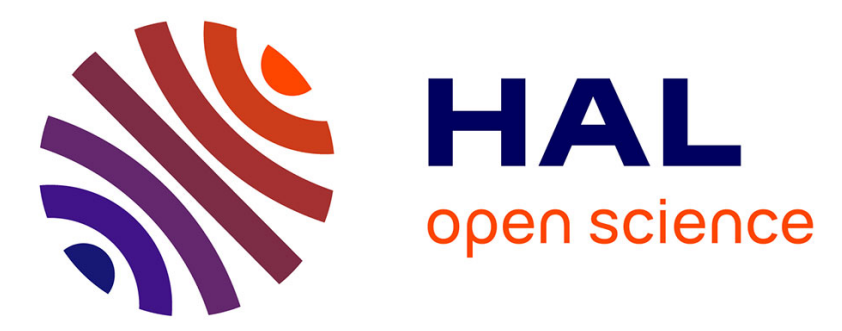

\title{
Porphyrin-functionalized mesoporous organosilica nanoparticles for two-photon imaging of cancer cells and drug delivery
}

Chiara Mauriello-Jimenez, Jonas Croissant, Marie Maynadier, Xavier Cattoën, Michel Wong Chi Man, Julien Vergnaud, Vincent Chaleix, Vincent Sol, Marcel Garcia, Magali Gary-Bobo, et al.

\section{To cite this version:}

Chiara Mauriello-Jimenez, Jonas Croissant, Marie Maynadier, Xavier Cattoën, Michel Wong Chi Man, et al.. Porphyrin-functionalized mesoporous organosilica nanoparticles for two-photon imaging of cancer cells and drug delivery. Journal of Materials Chemistry B: Materials for Biology and Medicine, 2015, 3 (18), pp.3681-3684. 10.1039/C5TB00315F . hal-01199618

\section{HAL Id: hal-01199618 \\ https://hal.science/hal-01199618}

Submitted on 16 Feb 2022

HAL is a multi-disciplinary open access archive for the deposit and dissemination of scientific research documents, whether they are published or not. The documents may come from teaching and research institutions in France or abroad, or from public or private research centers.
L'archive ouverte pluridisciplinaire HAL, est destinée au dépôt et à la diffusion de documents scientifiques de niveau recherche, publiés ou non, émanant des établissements d'enseignement et de recherche français ou étrangers, des laboratoires publics ou privés. 


\section{Journal of \\ Materials Chemistry B}

Accepted Manuscript

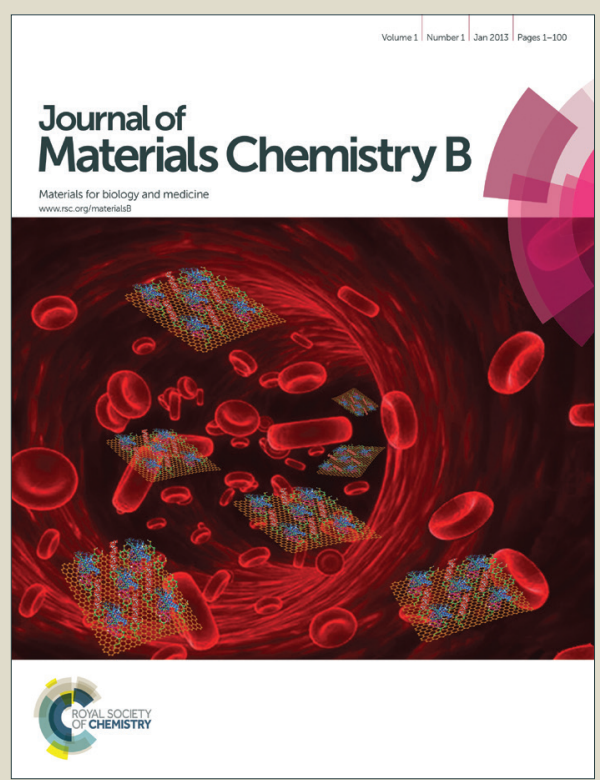

This is an Accepted Manuscript, which has been through the Royal Society of Chemistry peer review process and has been accepted for publication.

Accepted Manuscripts are published online shortly after acceptance, before technical editing, formatting and proof reading. Using this free service, authors can make their results available to the community, in citable form, before we publish the edited article. We will replace this Accepted Manuscript with the edited and formatted Advance Article as soon as it is available.

You can find more information about Accepted Manuscripts in the Information for Authors.

Please note that technical editing may introduce minor changes to the text and/or graphics, which may alter content. The journal's standard Terms \& Conditions and the Ethical guidelines still apply. In no event shall the Royal Society of Chemistry be held responsible for any errors or omissions in this Accepted Manuscript or any consequences arising from the use of any information it contains. 


\section{Journal of Materials Chemistry B}

\section{COMMUNICATION}

\section{Porphyrin-Functionalized Mesoporous Organosilica Nanoparticles for Two-Photon Imaging of Cancer Cells and Drug Delivery.}

Received ooth January 2012,

Accepted ooth January 2012

DOI: $10.1039 / \times 0 x x 00000 x$
Chiara Mauriello-Jimenez, ${ }^{a}$ Jonas Croissant, ${ }^{a}$ Marie Maynadier, ${ }^{d}$ Xavier Cattoën, ${ }^{c}$

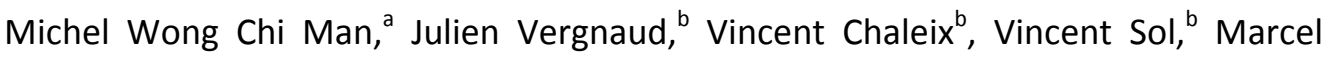
Garcia, ${ }^{d}$ Magali Gary-Bobo*, ${ }^{d}$ Laurence Raehm, ${ }^{a}$ and Jean-Olivier Durand* ${ }^{a}$

www.rsc.org/

The synthesis of a zinc porphyrin derivative possessing eight triethoxysilyl groups was performed through a CuAAC-click reaction. This porphyrin was covalently entrapped in ethenylene-bridged mesoporous organosilica nanoparticles which efficiently allowed performing doxorubicin delivery and two-photon imaging of breast cancer cells.

Mesoporous organosilica nanoparticles have very recently attracted much attention for applications in nanomedicine. ${ }^{1-8}$ Such nanoparticles are based on a silsesquioxane framework and an organic fragment which constitutes the structure of the material and which tailors their properties. ${ }^{9-12}$ These nanoparticles are very promising for cancer theranostics due to their low hemolytic properties, ${ }^{10}$ high biocompatibility, ${ }^{5}$ and high drug uptake and release capacities. Hollow mesoporous organosilica nanoparticles were prepared for $\mathrm{pH}$-triggered drug and gene delivery, high intensity focused ultrasounds imaging and drug delivery. ${ }^{2}$ Glutathione-triggered biodegradation of mesoporous organosilica nanoparticles was also reported. ${ }^{4,8}$

Two-photon excitation of nanoparticles has been demonstrated to be a promising strategy for in-vitro and in-vivo biomedical imaging applications. $^{13-16}$ Indeed, two-photon excitation provides a tridimensional spatial resolution with a typical resolution of a micron, while the combination with near-infrared excitation enhances the tissue penetration with a safer treatment. ${ }^{13-15,17-19}$ We have recently described periodic mesoporous organosilica nanoparticles for two photon-imaging, therapy and drug delivery. ${ }^{7}$ These nanoparticles incorporated a photosensitizer designed for two-photon excitation and allowed two-photon fluorescence imaging of breast cancer cells at $760 \mathrm{~nm}$.

As an alternative to a two-photon photosensitizer, we show here that a porphyrin derivative possessing eight trialkoxysilyl groups could be successfully covalently incorporated within ethenylenebridged mesoporous organosilica nanoparticles (EP NPs) and enabled two-photon fluorescence imaging of cancer cells at low laser power. These nanoparticles, when loaded with doxorubicin, induced very efficiently cancer cell killing at low concentration of nanoparticles.

To synthesize mesoporous organosilica nanoparticles containing the zink-porphyrin moiety, a new sol-gel precursor featuring 8 triethoxysilyl groups was designed. It was obtained in high yield from $\mathrm{Zn}(\mathrm{II})-5,10,15,20$-Tetrakis(4-(azidomethyl)-phenyl)porphyrin 20 through the CuAAC reaction 21,22 with $N, N$-bis(3triethoxysilylpropyl)prop-2-yn-1-amine in mild conditions, under microwave irradiation (ESI Scheme S1). The preparation of the EP NPs (Scheme S1) was carried out in water at $80{ }^{\circ} \mathrm{C}$, using cetyltrimethylammonium bromide as the structure-directing agent under basic catalysis. Bis(triethoxysilyl)ethene (E) and porphyrin 1 were co-condensed under these conditions. After 2 hours, the nanoparticles were centrifuged and the template extracted with ammonium nitrate.

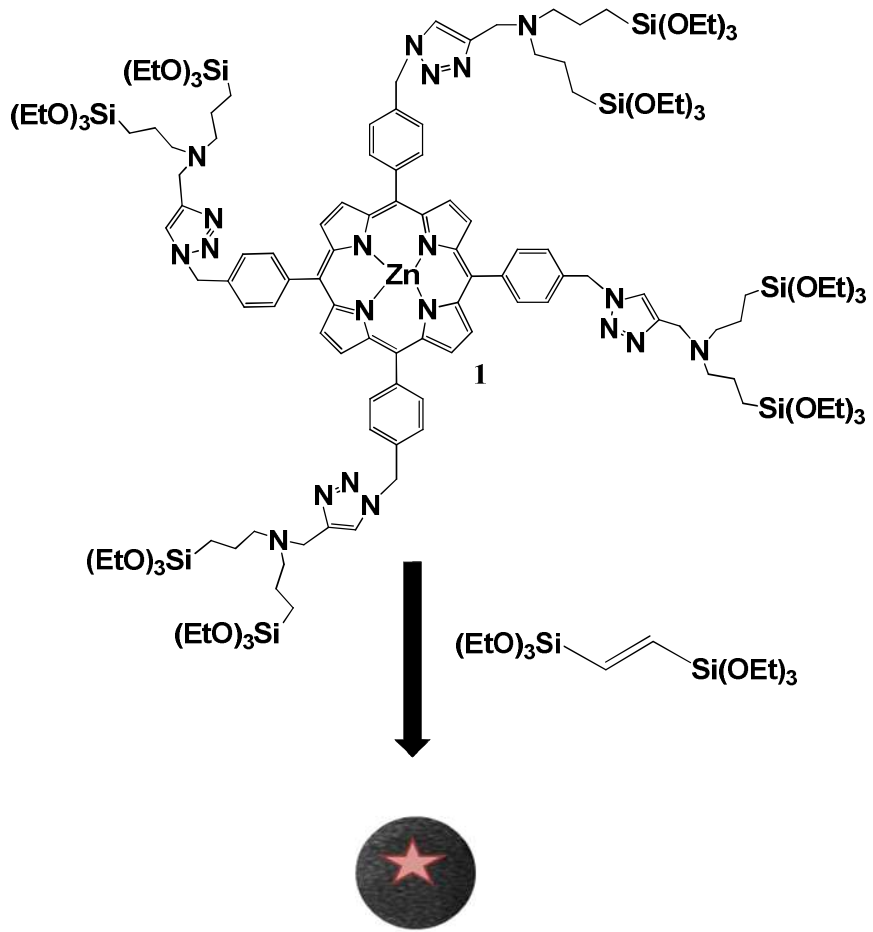

Scheme 1: Synthesis of EP NPs from bistriethoxysilylethene and porphyrin 1. 
The morphology and structure of the EP material were then characterized via various techniques. Transmission electron micrographs (TEM) revealed spherical nanoparticle with rough surfaces and diameter ranging from 200 to $600 \mathrm{~nm}$ (Figure 1A). Dynamic light scattering (DLS) confirmed the nano-size of the material with an average hydrodynamic diameter of $460 \mathrm{~nm}$ (Figure 1B). Nitrogen adsorption-desorption analysis showed that the NPs are mesoporous, with a type IV isotherm. A very high specific surface area of $1400 \mathrm{~m}^{2} \cdot \mathrm{g}^{-1}$, with an average pore diameter of $2.5 \mathrm{~nm}$ were deduced using the Brunauer-Emmett-Teller (BET) and Barrett, Joyner et Halenda (BJH) theories (Figure S1). A wormlike porosity was observed by TEM at higher magnification (see image on the right in Figure 1A), consistent with the small angle X-ray diffraction pattern which showed a broad peak at 2.2 degrees (Figure S2).

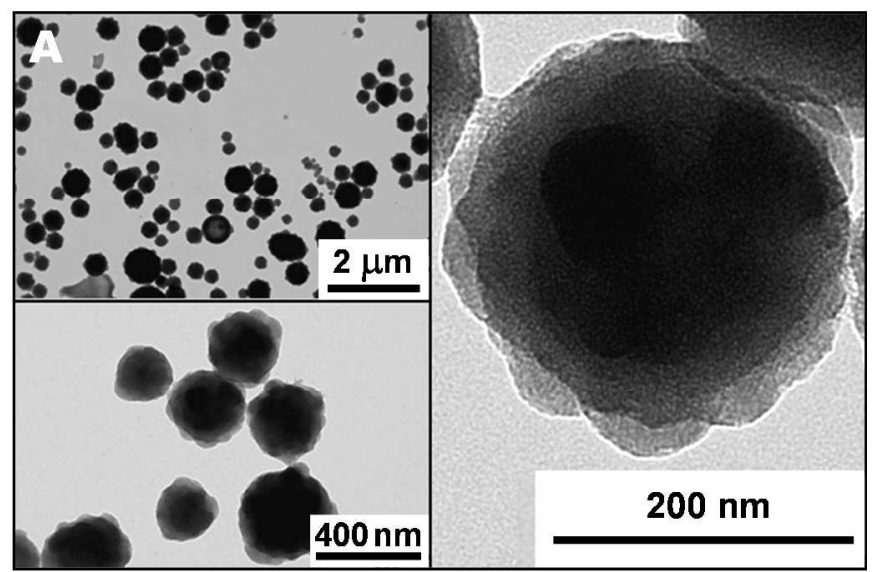

B

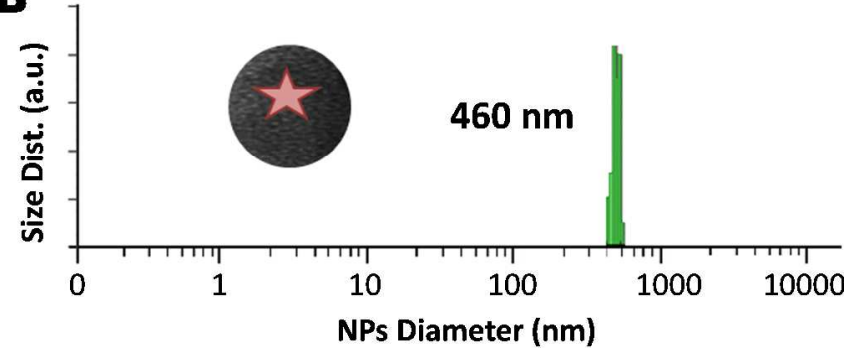

Figure 1: TEM images (A) and DLS size distribution (B) of the EP NPs.

The composition and photophysical properties of the two-photonsensitive nanomaterial were then investigated. First, the successful incorporation of the porphyrin fragments was clearly seen from the UV-Vis spectrum of EP NPs with the band at $430 \mathrm{~nm}$ (see Figure 2). Elemental analysis of nitrogen was used to determine the porphyrin content in the NPs, which was $0.04 \mathrm{mmol} / \mathrm{g}$ (ESI). The wide angle X-ray diffraction pattern only showed a broad peak at $20^{\circ}$, corresponding to non-regular repetitions within the siloxane framework (Figure S3), without any sharp peak that would evidence regular repetition of organics within the structure. The presence of only $\mathrm{R}_{-} \mathrm{SiO}_{3}$ environments was checked by ${ }^{29} \mathrm{Si} \mathrm{CP}-\mathrm{MAS}$ NMR (Figure S5). Fourier transform infrared (FTIR) and ${ }^{13} \mathrm{C}$ nuclear magnetic resonance (NMR) spectroscopies (see Figures S4 and S5) confirmed the presence of the ethenylene and the porphyrin bridges. It is noteworthy that the zeta potential was positive (Figure S6 ESI), due to the protonation of the tertiary amines at $\mathrm{pH} 7.4$ and 5.5. Additionally, as shown by the UV-Vis spectrum (Figure 2), the porphyrin moiety was clearly aggregated inside the nanoparticles. Indeed, the Soret band was enlarged and Q bands shifted to the red which suggests the presence of $J$ aggregates. ${ }^{23}$ Porphyrins usually

have a low two-photon absorption cross-section but $J$ aggregation of porphyrin derivatives is known to increase the two-photon absorption cross-section. ${ }^{24}$

Consequently, the two-photon imaging capacity of the EP NPs was assessed in cancer cells. The cytotoxicity of the nanoparticles on MCF-7 breast cancer cells was measured with the MTT assay, and the percentage of living cells was high, up to a concentration of 50 $\mu \mathrm{g} \cdot \mathrm{mL}^{-1}$ (see Figure S7). Then, the nanomaterial was incubated for $20 \mathrm{~h}$ in MCF-7 breast cancer cells. The cellular uptake was determined via two-photon fluorescence imaging (TPEF). The laser excitation was performed with a Carl Zeiss two-photon confocal microscope at low power $(2.8 \%$ of the input power) at different wavelengths. The cell membranes were stained with Cell Mask 15 min before the imaging experiments. EP NPs were successfully endocytosed by cancer cells as shown by TPEF at 750 and $800 \mathrm{~nm}$ (see Figure $3 \mathrm{~A}$ and $\mathrm{B}$ respectively). Thus, these findings demonstrate the suitability of porphyrin-functionalized mesoporous organosilica nanoparticles for two-photon imaging.

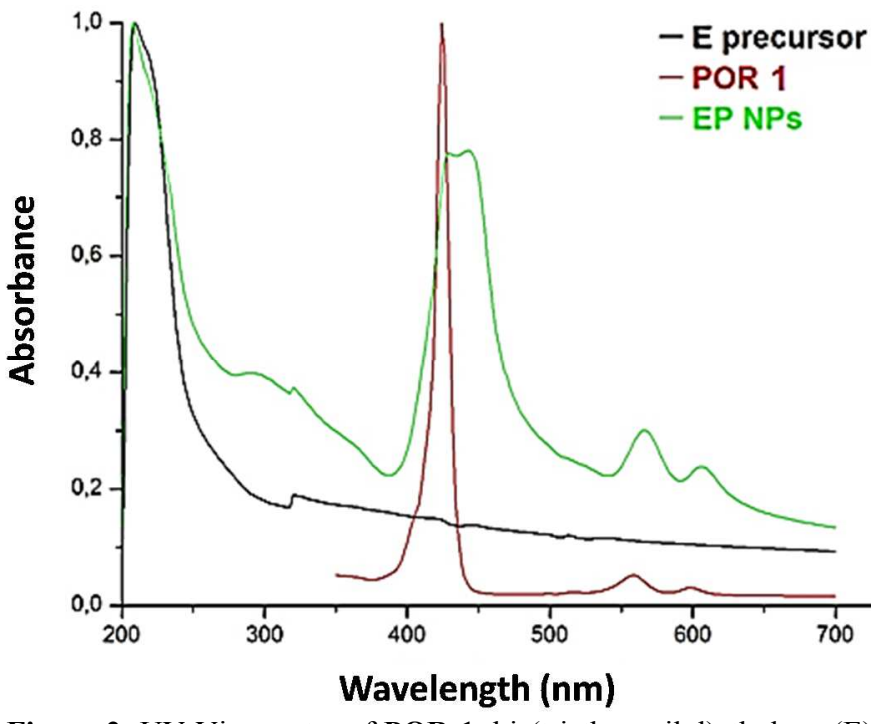

Figure 2: UV-Vis spectra of POR 1, bis(triethoxysilyl)ethylene (E) and EP NPs in EtOH.

A
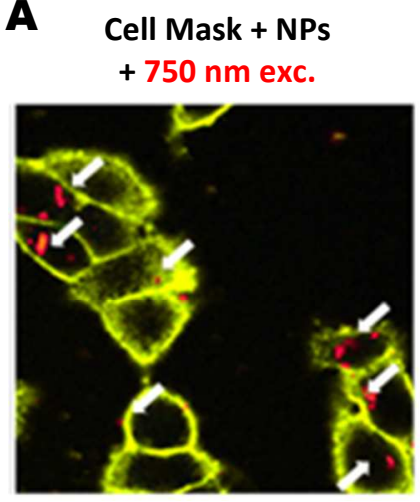

B

Cell Mask + NPs $+800 \mathrm{~nm}$ exc.

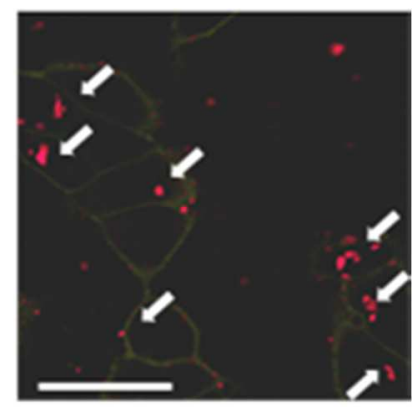

Figure 3: Two-photon fluorescence imaging of MCF-7 breast cancer cells. Cell membranes were stained with Cell Mask TM Orange Plasma Membrane, EP NPs were incubated and irradiated at 750 (A) and $800 \mathrm{~nm}$ (B). Arrows indicate NPs in cells. Scale bar $10 \mu \mathrm{m}$.

Owing to their high porosity, the nanoparticles were then applied as drug nano-carriers. EP NPs were loaded with doxorubicin at $\mathrm{pH} 5.5^{4}$ 
and the drug loading was $20 \mathrm{wt} \%$. The release of doxorubicin has been studied with similar systems and was $\mathrm{pH}$ dependent. ${ }^{4,7}$ Therefore EP NPs were incubated with MCF-7 for $72 \mathrm{~h}$ and found to be remarkably efficient to cause cell death as only $25 \%$ of cancer cells survived at a concentration of EP NPs of only $1 \mu \mathrm{g} \cdot \mathrm{mL}^{-1}$ (see F(बुre 4).

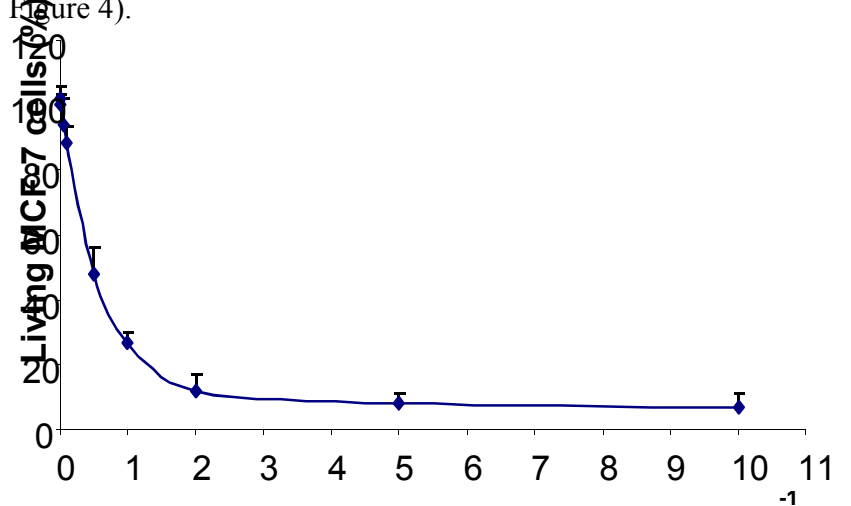

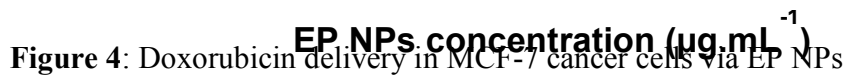

\section{Conclusions}

We have prepared an octa-trialkoxysilane-substituted $\mathrm{Zn}$ porphyrin which was successfully covalently incorporated in ethenylene-bridged mesoporous organosilica nanoparticles. The nanoscaled particles displayed a very high specific surface area, enabling drug loading and release. Moreover, the aggregation of the porphyrin derivative within the mesopores enabled potent two-photon fluorescence imaging of breast cancer cells. Furthermore, the doxorubicin-loaded organosilica nanoparticles were very efficient to induce cancer cell killing showing promising potential for theranostic applications.

\section{Notes and references}

a) Institut Charles Gerhardt Montpellier, UMR-5253 CNRS-UM2-ENSCMUM1cc 1701, Place Eugène Bataillon F-34095 Montpellier cedex 05. (France) Fax: +33-467-143-852, E-mail: urand@um2.fr.

b) Laboratoire de Chimie des Substances Naturelles, EA 1069, Université de Limoges, Faculté des Sciences et Techniques, 123 avenue A. Thomas 87060 Limoges cedex, France.

c) Institut Néel, CNRS and Université Grenoble-Alpes, 38042 Grenoble, France

d) Institut des Biomolécules Max Mousseron UMR 5247 CNRS; UM 1; UM 2 - Faculté de Pharmacie, 15 Avenue Charles Flahault, 34093 Montpellier Cedex 05, France. E-mail: magali.gary-bobo@univ-montp1.fr

d) NanoMedSyn, Faculté de Pharmacie, 15 Avenue Charles Flahault, 34093 Montpellier Cedex 05, France. E-mail: magali.gary-bobo@univ-montp1.fr

$\dagger$ Footnotes should appear here. These might include comments relevant to but not central to the matter under discussion, limited experimental and spectral data, and crystallographic data.

Electronic Supplementary Information (ESI) available: [Experimental details of porphyrin 1 and EP NPs syntheses, X-ray diffraction patterns, solid-state NMR, BET, Zeta potential, Cytotoxicity of EP NPs, experimental details on two-photon imaging and doxorubicin delivery]. See DOI: $10.1039 / \mathrm{c} 000000 \mathrm{x} /$

1. M. Wu, Y. Chen, L. Zhang, X. Li, X. Cai, Y. Du, L. Zhang and J. Shi, J. Mater. Chem. B, 2015, 3, 766-775.

2. X. Qian, W. Wang, W. Kong and Y. Chen, RSC Adv., 2014, 4, 17950-17958.

3. X. Li, L. Zhou, Y. Wei, A. M. El-Toni, F. Zhang and D. Zhao, J. Am. Chem. Soc., 2014, 136, 15086-15092.

4. J. Croissant, X. Cattoen, M. W. C. Man, A. Gallud, L. Raehm, P. Trens, M. Maynadier and J.-O. Durand, Adv. Mater., 2014, 26, 6174-6178.

5. Y. Chen, P. Xu, H. Chen, Y. Li, W. Bu, Z. Shu, Y. Li, J. Zhang, L. Zhang, L. Pan, X. Cui, Z. Hua, J. Wang, L. Zhang and J. Shi, Adv. Mater., 2013, 25, 3100-3105.

6. B. Guan, Y. Cui, Z. Ren, Z.-a. Qiao, L. Wang, Y. Liu and Q. Huo, Nanoscale, 2012, 4, 6588-6596.

7. J. Croissant, D. Salles, M. Maynadier, O. Mongin, V. Hugues, M. Blanchard-Desce, X. Cattoen, M. Wong Chi Man, A. Gallud, M. Garcia, M. Gary-Bobo, L. Raehm and J.-O. Durand, Chem. Mater., 2014, 26, 7214-7220.

8. Y. Chen, Q. Meng, M. Wu, S. Wang, P. Xu, H. Chen, Y. Li, L. Zhang, L. Wang and J. Shi, J. Am. Chem. Soc., 2014, 136, 16326-16334.

9. J. Croissant, X. Cattoen, M. Wong Chi Man, P. Dieudonne, C. Charnay, L. Raehm and J.-O. Durand, Adv. Mater., 2015, 27, 145-149.

10. C. Urata, H. Yamada, R. Wakabayashi, Y. Aoyama, S. Hirosawa, S. Arai, S. Takeoka, Y. Yamauchi and K. Kuroda, J. Am. Chem. Soc., 2011, 133, 8102-8105.

11. N. Mizoshita, T. Tani and S. Inagaki, Chem. Soc. Rev., 2011, 40, 789-800.

12. P. Van Der Voort, D. Esquivel, E. De Canck, F. Goethals, I. Van Driessche and F. J. Romero-Salguero, Chem. Soc. Rev., 2013, 42, 3913-3955.

13. J. Dimitrijevic, L. Krapf, C. Wolter, C. Schmidtke, J.-P. Merkl, T. Jochum, A. Kornowski, A. Schueth, A. Gebert, G. Huettmann, T. Vossmeyer and H. Weller, Nanoscale, 2014, 6, 1041310422.

14. D. Ding, C. C. Goh, G. Feng, Z. Zhao, J. Liu, R. Liu, N. Tomczak, J. Geng, B. Z. Tang, L. G. Ng and B. Liu, Adv. Mater., 2013, 25, 6083-6088.

15. M. Gary-Bobo, Y. Mir, C. Rouxel, D. Brevet, I. Basile, M. Maynadier, O. Vaillant, O. Mongin, M. Blanchard-Desce, A. Morère, M. Garcia, J.-O. Durand and L. Raehm, Angew. Chem. Int. Ed., 2011, 50, 11425-11429.

16. V. Lebret, L. Raehm, J. O. Durand, M. Smaihi, M. H. V. Werts, M. Blanchard-Desce, D. Methy-Gonnod and C. Dubernet, $J$. Biomed. Nanotechnol., 2010, 6, 176-180.

17. J. Croissant, A. Chaix, O. Mongin, M. Wang, S. Clément, L. Raehm, J.-O. Durand, V. Hugues, M. Blanchard-Desce, M. Maynadier, A. Gallud, M. Gary-Bobo, M. Garcia, J. Lu, F. Tamanoi, D. P. Ferris, D. Tarn and J. I. Zink, Small, 2014, 10, 1752-1755.

18. J. Croissant, M. Maynadier, O. Mongin, V. Hugues, M. BlanchardDesce, A. Chaix, X. Cattoën, M. Wong Chi Man, A. Gallud, 
M. Gary-Bobo, M. Garcia, L. Raehm and J.-O. Durand, Small, 2014, 11, 295-299.

19. J. Croissant, M. Maynadier, A. Gallud, H. Peindy N'Dongo, J. L. Nyalosaso, G. Derrien, C. Charnay, J.-O. Durand, L. Raehm, F. Serein-Spirau, N. Cheminet, T. Jarrosson, O. Mongin, M. Blanchard-Desce, M. Gary-Bobo, M. Garcia, J. Lu, F. Tamanoi, D. Tarn, T. M. Guardado-Alvarez and J. I. Zink, Angew. Chem. Int. Ed., 2013, 52, 13813-13817.

20. A. Eggenspiller, C. Michelin, N. Desbois, P. Richard, J. M. Barbe, F. Denat, C. Licona, C. Gaiddon, A. Sayeh, P. Choquet and C. P. Gros, Eur. J. Org. Chem., 2013, 2013, 6629-6643.
21. K. Burglova, A. Noureddine, J. Hodacova, G. Toquer, X. Cattoen and M. Wong Chi Man, Chem. Eur. J., 2014, 29, 10371-10382.

22. X. Cattoën, A. Noureddine, J. Croissant, N. Moitra, K. Bürglová, J. Hodačová, O. Cobos, M. Lejeune, F. Rossignol, D. Toulemon, S. Bégin-Colin, B. Pichon, L. Raehm, J.-O. Durand and M. Wong Chi Man, J. Sol-Gel Sci. Technol., 2014, 70, 245-253.

23. R. Giovannetti, The use of Spectrophotometry UV-Vis for the Study of Porphyrins, Macro To Nano Spectroscopy, Dr. Jamal Uddin (Ed.), 2012.

24. P. C. Ray and Z. Sainudeen, J. Phys. Chem. A, 2006, 110, $12342-$ 12347. 


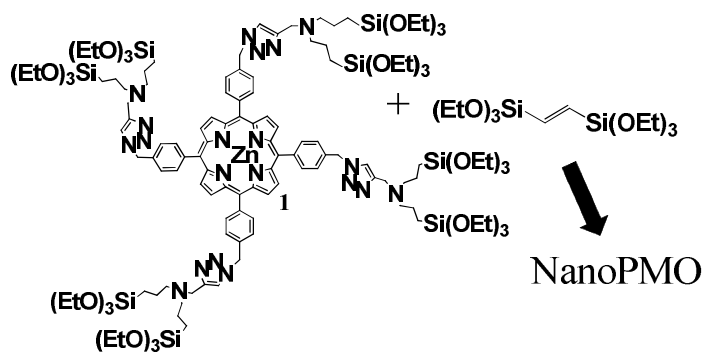

The synthesis of porphyrin-functionalized ethylene-based Mesoporous Organosilica Nanoparticles was performed. 